\title{
Environmental Challenges of Postindustrial Economy
}

\author{
Tatiana Gvozdkova ${ }^{1, *}$, Anna Lozhnikova $^{2}$, Yulia Suslova ${ }^{3}$, and Seroni Anyona ${ }^{4}$ \\ ${ }^{1}$ Kuzbass State Technical University, Mezhdurechensk branch, 652881, Stroitelei Avenue, 36, \\ Mezhdurechensk, Russia \\ ${ }^{2}$ National Research Tomsk State University, 634050, 36 Lenina ave, Tomsk, Russia \\ ${ }^{3}$ Siberian Federal University, 660075 Lida Prushinskaya St. 2, Krasnoyarsk, Russia \\ ${ }^{4}$ Jomo Kenyatta University of Agriculture \& Technology, Mining, Materials \& Petroleum \\ Engineering Department, P.O. Box 62000 - 00200, Nairobi, Kenya
}

\begin{abstract}
The responsibility of the modern industrial society for the growth of the global environmental crisis does not raise any doubts. It is also generally accepted that the solution of global environmental problems is associated with a change in the way of life of the population of developed countries, whose maintenance at a high level requires a steady growth of the economy, which until recently was ensured by the extensive use of natural resources. The functioning of such a model of economic production has led not only to the depletion of natural potential, but also to the production of a huge amount of waste. The need to increase economic growth reflects a universal setting for the industrial (and later the post-industrial) society on the growth of the material well-being of the population. The lifestyle formed on the basis of consumer culture enlightens the relationship between society and environment, stimulating economic development, because a market economy cannot develop without an increase in consumption. The society responds to the new needs by accelerating scientific and technological progress to the postindustrial level, which, in accordance with the dominant attitudes in the public consciousness, is perceived both as a foundation of material well-being and as a foundation for the conquest of nature.
\end{abstract}

\section{Introduction}

The aggravation of environmental problems has become a logical result of the evolution of industrial society with its inherent values, ideas and attitudes, which, according to some researchers, determine the content of the "dominant technological paradigm" that guides the development of the attitude to environment at each historical time interval [1]. Following its own logic, industrial society from the "welfare society" was transformed into a "society of universal risk", unable to control the spread of environmental man-made risks generated by

\footnotetext{
* Corresponding author: kuzstu@,inbox.ru
} 
it. The continued existence of such a society with its installation on the continuous buildup of material goods to the detriment of nature has become a source of constant economic, social and environmental threat. In addition, the very buildup of material benefits began to run into the limited biological resources of the planet.

The direct connection between economic growth and an increase in anthropogenic pressure is direct, which induces many scientists to see the resolution of the conflict between society and nature in limiting economic growth or even abandoning it. This idea, raised by the Rome Club back in the 1970s, has quite a few supporters, but it also raises many objections [2]. Not only the question of the desired borders of this limitation remains open, the possibility of accepting it, as a matter of limiting material needs stays problematic for the near future.

During the transition to the postindustrial phase, the industrial world showed openness to the perception of the ecological imperative as a conscious need to search for new development guidelines. The formation and distribution of environmental needs in industrialized countries marked a certain historical milestone in the evolution of technological civilization, when it faced the need for its further modernization.

The industrial world, spawning the middle class with its demands for quality of life that go beyond the traditional values of the industrial age, laid the foundations for future environmental modernization. Concerns about the proliferation of environmental risks were expressed in the spread of the mass ecological movement, which could not but cause an adequate reaction of political power, driven by the interests of preserving the stability of the system. Satisfying environmental needs, closely related to social ones, is becoming a new direction of the welfare state. The result of the search for measures to harmonize the interests of social and ecological development was the strengthening of the regulatory role of the state in the environmental sphere at the turn of the 1970s-1980s. As a result of environmental protection measures in Western Europe and the United States, it was possible to reduce the burden on the environment with an increase in the volume of economic activity [3].

Satisfied with the successes achieved in the environmental field, the active part of the population shifted the burden of social and material responsibility for maintaining environmental purity to industrial companies, and the control functions - to the state and nongovernmental organizations. Nevertheless, people previously supported the environmental movement has stepped aside, demonstrating immunity to any changes in the usual image of life. Reduction of environmental interest of society, and, accordingly, the weakening of the political influence of pro-ecologically-minded groups in the United States and Western Europe (excluding Germany) in the 1990s are the reactions of the population to the threat of traditional material interests infringement and the evidence of its unwillingness to accept an alternative lifestyle and "postmaterial values", expressed by the radical vanguard of nature protection.

Having distanced themselves from active participation in environmental policy, the population of developed industrialized countries nevertheless retained the possibility of greening the economy through the market mechanism of supply and demand. Maintaining its quality of life requirements at a high level, developed population affects consumer demand, and through it, to a certain extent, the economic activity. Environmental requirements for the quality of goods and the method of their production are increasing from year to year. Now there is a widespread "fashion" on environmentally friendly products. However, as evidenced by a survey of young people in Japan, the degree of their concern for environmental issues and their willingness to acquire more expensive environmental products are not interrelated indicators [4]. 


\section{Materials and Methods}

With the transition to a policy of preventing environmental degradation - namely, this goal underlies the environmental policy at the present stage - the emphasis in environmental activities has shifted from the use of mainly administrative levers to the use of market mechanisms of environmental regulation. The introduction of payments for environmental management, differentiated taxes on emissions, systems for the sale of pollution rights, along with stricter environmental requirements, are designed to increase the interest of entrepreneurship in the implementation of environmental protection measures. The use of such a system not only provides budget savings, but also stimulates the business in order to avoid unnecessary costs to look for new technical means of environmental safety.

The latest estimates show that with the introduction of modern technology, the efficiency of using natural resources is quadrupled. In short, you can live twice as good by consuming half the natural resources. However, the transition to a new strategy for solving environmental problems is possible only when a consensus is established between the state and business, based on an awareness of the economic feasibility of investing in environmental projects.

The introduction of business to new environmental imperatives is a necessary form of its adaptation to the requirements of the time - economical, technological, moral and ethical. The pressure of public opinion, on the one hand, and the strengthening of the regulatory function of the state, on the other, force businesses to look for new forms of participation in environmental activities in order to avoid unnecessary costs [5]. This goal is served by the widespread system of voluntary commitments, the adoption of which allows entrepreneurs to take into account environmental changes in the market in advance and adapt to them with less losses, which are much higher if the state imposes more severe sanctions on nature suppressors under public pressure. To gain public recognition and get support for environmental activities means to secure a competitive advantage and gain stability in the domestic and foreign markets. The fear of being ousted from European markets with their high demands for the environmental quality of goods and services has stimulated Japanese companies to adopt a new internationally-certified ISO-14000 certification system [6]. Maintaining their competitiveness is the main problem for the Japanese industry, which, according to American experts from the International Corporation for Ecological Business, is somewhat inferior (86 points) to American (99.5 points) and Western European (98 points).

Companies that have adopted an environmental code undertake "not to produce products and not offer services that do not meet environmental needs and do not meet energy saving needs" [7-8]. An increasing number of companies are adopting a sustainable development strategy and are committed to following it, using the emerging external context in order to strengthen their own competitive positions. Quite a few companies have already come to understand that "business excellence and environmental concerns cannot be divided," and "tomorrow's winners will be those who are already more successful today in improving their eco-efficiency" [9].

According to the representatives of the business community, their participation in the implementation of the concept of sustainable development is determined by eco-efficiency. This is the best option for today to ensure a balance between public and private interests, between the needs of economic profitability and environmental sustainability. A few years ago, the requirements of environmental protection and sustainable development were considered by business as a risk factor, today it is recognized that "measures to prevent pollution pay for themselves". For example, the net profit from the introduction in 1990 of a new law on "Clean Air" in the United States was estimated by 1995 at $\$ 90$ billion [10]. 


\section{Results and Discussion}

The most active in the implementation of "green" projects are "environmentally hazardous" production (cement, steel, petrochemical) enterprises. For example, Shell Company, while remaining one of the three leading global oil and gas companies, at the same time shows considerable interest in projects for the development of alternative energy sources, which are projected to meet $10 \%$ of global energy demand by 2020 and $50 \%$ to the midcentury [11]. Development in the field of solar energy is now actively engaged with the support of the state and the companies in Germany and Japan. The future is for those who are already considering future demand in the world market. Within 15 years, the range of manufactured products will change by $50 \%$. Many large companies build their development strategy, first, based on the emerging public opinion. For example, the DuPont company, hoping to take a leading position in the global production of medicines and the development of new varieties of grain, chose the United States to invest in the development of the highly profitable industry of genetic engineering not occasionally, because there are no concerns about genetically modified varieties, unlikely in Western Europe [12].

Nevertheless, all what has been said above about the "corporate environmentalism" of entrepreneurship, refers primarily to the activities of the world's largest corporations, which have considerable funds to invest in the development of new technologies. Environmental needs, on the one hand, aggravate competition. On the other hand, they "consolidate" the economic advantage of large companies that are in a more favorable (financial, technological) position. At the same time, it is large companies, and above all their activities in the field of ecology, that are becoming the object of close attention and control by the public. It is largely promoted by the information revolution, which makes it possible to uncover the operations of transnational corporations that were previously carried out with serious environmental violations, to the public. At the same time, as the US experience shows, the changes that have occurred in the depths of the largest transnational corporations, eventually, are embodied in various laws and regulations, exerting a direct impact on environmental protection activities of any scale.

In modern post-industrial society, environmental interest is becoming a factor in the intensification of economic development. Conducting consistent environmental activities accelerates economic progress, since both economic growth and environmental protection have a common basis - technological progress. Environmental programs stimulate the development of the economy, the implementation of structural reforms, the creation of new jobs and further scientific and technical progress. Starting in the 1970s, developed countries demonstrate significant progress in energy conservation, thereby confirming the lack of a direct link between increased economic production and increased energy consumption. According to IMF estimates, the consumption of natural resources per unit of annual output is reduced annually by $1.23 \%$. Significantly expanded the scope of recycling of raw materials. In Germany, agricultural waste is utilized by $90 \%$, machine bodies - by $98 \%$, waste oils - by $90 \%$ ). In Japan, a green business is rapidly developing, with annual growth exceeding $6 \%$. According to official data, the domestic market for "green" products and services is estimated at 5 trillion yen and is equivalent in value to the entire vehicle manufacturing industry, exceeding the broadcast and telecommunications sector [10].

At the same time, the ecological "effect" of the post-industrial society is also achieved due to shifts in the structure of the national economy, when high-tech industries replace energy-intensive ones, gradually moving to other countries.

Nonetheless, the greening of economic activity in a post-industrial society is extremely controversial, reflecting the duality of the public perception of development goals, while maintaining the same setting in the public consciousness on the growth of material wellbeing. Therefore, despite the implementation of strict control measures, the ecological 
situation not only does not improve, but also, on the contrary, threatens to turn into catastrophic - there is a steady deterioration in all global environmental characteristics. In recent years, new problems have arisen: pressure on renewable and non-renewable natural resources has increased, problems related to the development of transport have become more acute. The measures taken in the developed world to prevent environmental catastrophe are clearly insufficient to achieve the stated goal, moreover, they are often disordered and random in their nature.

The point of the main effort moves from the particular task of environmental protection to a more general task - balanced sustainable development. Meanwhile, this goal of development is still very poorly recognized by society. The question of the prospects for implementing sustainable development in post-industrial countries remains open. So far, there is no answer to the main question: can the modern economy provide a technical solution to environmental problems, while maintaining an orientation towards the most complete satisfaction of the needs of the population, which in turn has to cope with an even more difficult task - changing their lifestyle. The modern post-industrial society, having laid the foundations of economic modernization, has faced problems that cannot be solved today the limited scientific and technical base for preventing an environmental crisis and the lack of awareness of the importance of the tasks facing the majority of the population. The possibilities of further ecological modernization of the post-industrial society have their own technological and ideological limits.

The change of technology on average occurs in 10 years. But the policy of developing and introducing environmentally friendly technologies into production is more in the interest of economic efficiency and increasing the competitiveness of production, and ensures longterm environmental safety only partially. The reduction in resource consumption per unit of finished product is negated by its overall increase due to the expansion of production. Despite the reduction in energy intensity of production, the total energy consumption, and accordingly, the amount of emissions of "greenhouse gases" is increasing.

No matter how significant is the role of entrepreneurship in the implementation of sustainable development, however, its own possibilities for greening production process are very limited. An environmental analysis of 56 countries showed that there is no direct correlation between the level of economic and environmental sustainability. Countries that are equal in terms of economic growth and competitiveness differ in environmental sustainability index. The overall environmental impact is dependent on the activities of any single company quite slightly, but mainly on the measures taken by government agencies, individual employees, individual consumers, and the lifestyle in general, the hopes and aspirations of the population.

The success of many previously conducted environmental programs is explained by the fact that the need to solve these problems was obvious, and the funds were relatively insignificant. The solution of the problems associated with the prevention of environmental degradation in the future is much more expensive. "Green" business is tied to the consumer, whose participation in the greening of economic activity is provided, often, for example, in Japan by law. Thus, consumers themselves partially collect and recycle household appliances, and homeowners also bear the costs of recycling construction in accordance with decrees adopted in the country. The production of energy-efficient, but more expensive cars is connected not only with technical innovations, but also with the willingness of buyers to pay a more expensive price for a new product, thereby paying back the costs incurred by the business to develop and introduce a new technology. 


\section{Conclusions}

Maintaining a healthy ecology requires not only incomparably large material costs from each person, but also changes in the lifestyle, and this task is hardly feasible for modern generation. Moreover, if a business is ready to recognize its environmental obligations to society and incur some costs, then the majority of the population lack awareness of their environmental responsibility, and therefore do not want to pay for environmental debt. In addition, it seems that the invariance of the adaptive capacities of each country, as well as of an individual, to the environmental challenges of our time, is determined by the influence of the technological factor. Today, the problem is not so much the spread of the mass environmental movement, as in the formation of environmental awareness. The paradox of a global problem facing postindustrial countries, like the world as a whole, is the need to perform two conflicting tasks: to provide people with new economic opportunities and to reduce the threat to the environment.

\section{References}

1. S. Zhironkin, D. Khloptsov, N. Skrylnikova, I. Petinenko, O. Zhironkina, E3S Web Conf., 41, 04010 (2018)

2. S. Zhironkin, S. Demchenko, G. Kayachev, M. Ryzhkova, O. Zhironkina, E3S Web Conf., 41, 04011 (2018)

3. S. Zhironkin, M. Gasanov, G. Barysheva, E. Gasanov, O. Zhironkina, G. Kayachev, E3S Web Conf., 21, 04002 (2017)

4. O. Kalenov, E. Shavina, E3S Web of Conf., 41, 04054 (2018)

5. S.A. Zhironkin, K.A. Kolotov, A.E. Genin, F.V. Agafonov, S.A. Kovalevsky, IOP Conf. Ser.: Earth Environ. Sci., 50:1, 012011 (2017)

6. S. Zhironkin, M. Gasanov, G. Barysheva, K. Kolotov, O. Zhironkina, E3S Web Conf., 15, 03012 (2017)

7. M. Cehlár, L. Mihok, Theoretical and Empirical Researches in Urban Management, 8:4, 60-72 (2013)

8. G. Alexandrov, A. Iablonev, E3S Web Conf., 41, 04024 (2018)

9. M. Cehlár, J. Janočko, Z. Šimková, T. Pavlik, M. Tyulenev, S. Zhironkin, M. Gasanov, Resources, 8:1, 21 (2019)

10. T.V. Kiseleva, V.G. Mikhailov, Economics and Innovation Management, 4, 70-78 (2018). DOI: 10.26730/2587-5574-2018-4-70-78

11. E. Dotsenko, N. Ezdina, S.Mudrova, E3S Web Conf., 41, 04050 (2018)

12. A. Kovalev, N. Rebrova, M. Zhidkova, E3S Web Conf., 41, 04026 (2018) 